\title{
THREE NEW GENERA OF THE HIGHER FUNGI.
}

\author{
GEO. F. A T K I N S N
}

(WITH THREE FIGURES)

I. EOMYCENELla, A NEW GenUS OF HyMENOMYCETES.

THIS interesting plant was found during September I899, on fallen leaves of Rhododendron maximum at Blowing rock, N. C. The plant is very minute, entirely white, possesses a delicate pileus which is broadly campanulate or depressed in age, and a very slender, fleshy stem. An examination with the hand lens showed that there were no lamellae, the underside of the pileus being plane. The Rhododendron leaves, partly dry, rolled in such a way as to protect the fungus, and in this condition it was shipped to Ithaca. On examination with a higher power microscope, it was found that the hymenium had dissolved so that the spores lay against the underside of the framework of the pileus in the amorphous layer of dissolved tissue. From this material it was clearly impossible to determine the structure of the fungus. The leaves were then placed in a moist chamber, and in the course of a few days a new plant appeared, and for some time successive ones grew and I was enabled to study the structure.

For some time none of the plants showed any trace of lamellae, and it appeared that the fungus belonged to the Thelephoraceae. but later one plant was grown somewhat larger than the others, which had rudimentary lamellae, eight of a larger size and four very small. This at once opens the question as to whether the plant belongs to the Thelephoraceae or to the Agaricaceae and whether originally the hymenial surface was plane, and the form with lamellae represents a later stage in the evolution of the plant; or whether the gill form represents the original character of the species, which by reduction loses its lamellae. The latter condition is seen sometimes in Marasmius epiphyllus Fr., ${ }^{\mathbf{x}}$ and I have

I Persoon, Icones pl. g. fig. 7. ; Stevenson, Brit. Fung., Hymen. 2 : 152. 
seen specimens of Lepiota procera in which large areas on the under side of the pileus were destitute of lamellae. The additional characters of the fungus are to be found in the following description :

EOMYCENELLA Atkinson, n. gen.-Plants stipitate. Pileus campanulate to expanded, consisting of a layer of radiating branched threads forming a more or less lattice-like or trabecular, expanded, thin structure; trama wanting or very rudimentary the subhymenium arising directly from the trabeculae of the pileus. Hymenium plane, or in larger forms with a few short, narrow, distant lamellae not reaching the stipe; lamellae with rudimentary trama. Basidia clavate, 4-spored. Spores smooth, I-celled, hyaline. Stipe fleshy, delicate. At maturity hymenium dissolving, leaving many of the spores lying on an amorphous layer against the trabeculae.-One species, on decaying leaves of Rhododendron maximum, Blowing rock, N. C.

Eomycenella echinocephala Atkinson, n. sp. $($ fig. I).-Plants white, $3-8{ }^{\mathrm{mm}}$ high. Pileus $0.5-0.75^{\mathrm{mm}}$ broad. Stipe $60-80 \mu$ in diameter. Plants campanulate to expanded and upturned in age, trabeculae of upper surface echinulate, bearing here and there 
globose free branches, IO-I $5 \mu$ in diameter and also echinulate, margin of pileus with free clavate branches in the form of a fringe. Cells of the trabeculae 25-30 $\times 6-10 \mu$. Hymenium plane or with few short, narrow gills. Gills when present narrowed at each end, not reaching the stipe. In the plant observed 8-1o long lamellae, 4-6 intermediate ones much shorter. Subhymenium loosely branched, obovate cells arising from the trabeculae and terminating in the basidia, or in the forms with lamellae arising from a rudimentary trama in the lamella. Basidia short clavate, abruptly narrowed into a pedicel, 9-1 $2 \times$ $6-9 \mu, 4$-spored. Spores obovate-oblong, elliptical, proximal end pointed, 6-8 $\times 3-4 \mu$, hyaline, smooth, granular. Stipe thread-like, with scattered hairs bearing a short echinulate cell on the end. Base of stipe only slightly broadened.

Eomycenella is related to Discocyphella ${ }^{2}$ P. Hennings, but differs in the dissolving hymenium and the fact that the pileus is not gelatinous nor the stem horny. From Cymatella ${ }^{3}$ Patouillard (placed with Agaricaceae) it differs in the trabecular pileus and the dissolving hymenium; and from Gloeocephala ${ }^{4}$ (Clavariaceae) Massee, which has one-spored basidia. The latter should be placed in the Thelephoraceae.

II. EOTERFEZIA, THE TYPE OF A NEW GENUS AND FAMILY OF ELAPHOMYCETES.

This fungus appeared as a parasite on Sordaria grown in the laboratory in the spring of 1897 . Cow dung which had been lying on the ground all winter was collected early in the spring of 1897 in a pasture field just beyond Buttermilk creek, near Ithaca, N. Y. This was placed in a moist chamber and in the course of a few weeks the Sordaria made its appearance. The species of Sordaria was not determined. After the cultures had been kept a week or so longer, there appeared on the perithecia of Sordaria minute white, knot-like protuberances which were smaller than the perithecia and stood out in strong contrast to the dark brown wall of the host. These minute bodies, subglobose or kidney shaped, were nearly smooth, possessing a few scattering free threads arising from the surface, and their texture was soft and fleshy.

${ }^{2}$ Engler and Pranti., Pflanzenfamilien $\mathrm{I}^{1}: 554 . \quad{ }^{3} \mathrm{Ibid}$. p. $555 .{ }^{4} \mathrm{Ibid}$. p. ${ }^{1} \mathrm{I}^{\mathrm{I}}$ 
On examination of the structure it was at once clear that the fungus was a very interesting one. Nearly the entire interior of the fruit body is occupied by minute asci, not collected into a single tuft as in the pyrenomycetes, but scattered and intermingled with the mycelium. The asci are separated into small fields by radiating strands or thin plates of mycelium, forming sterile avenues from which the branches arise that ultimately bear the asci and are intermingled with them. Since the fields of asci are more or less elongate and thin, they too, have a more or less radial direction from the point where the fruit body is in contact with the host. The surface of the fruit body is a thin and delicate wall formed by the coalescence of hyphae into a membranous envelop which is joined by the terminations of the radiating sterile avenues.

The arrangement of the asci in fields separated by sterile avenues of mycelium suggested that the fungus was related to the Tuberineae. However, the asci do not form a hymenium lining the walls of chambers in the interior, but they are irregularly intermingled in the fields which they occupy. This places the fungus definitely in the order Plectascineae. ${ }^{5}$ In Fischer's arrangement of this order there are six families. In the first three families, Gymnoascaceae, Aspergillaceae, and Onygenaceae, the asci are irregularly distributed throughout the interior of the fruit body, while in the Elaphomycetaceae and Terfeziaceae ${ }^{6}$ there are sterile avenues separating the fertile fields into groups. It is evident that our plant possesses certain points of close agreement with these two families, but the internal structure is much more simple, and the asci and spores are not so highly specialized, while the thin membranous, rudimentary envelop is very unlike the thick and differentiated wall of the members of these two families.

It is evidently a plant of very simple structure. It shows some points of resemblance in this respect with the Gymnoasca-

${ }^{5}$ Engler and Prantl, Pflanzenfamilien $I^{1}: 290$.

${ }^{6}$ The Trichocomaceae have a highly specialized and peculiar capillitium, too remote from our plant for comparison. 
ceae; but, as stated above, the differentiation of the interior into sterile avenues and fertile fields does not admit of its location in that family. Furthermore, the envelop of the fruit body in the Gymnoascaceae is arachnoid, while the envelop of our plant, though simple and very thin, is membranaceous. It represents

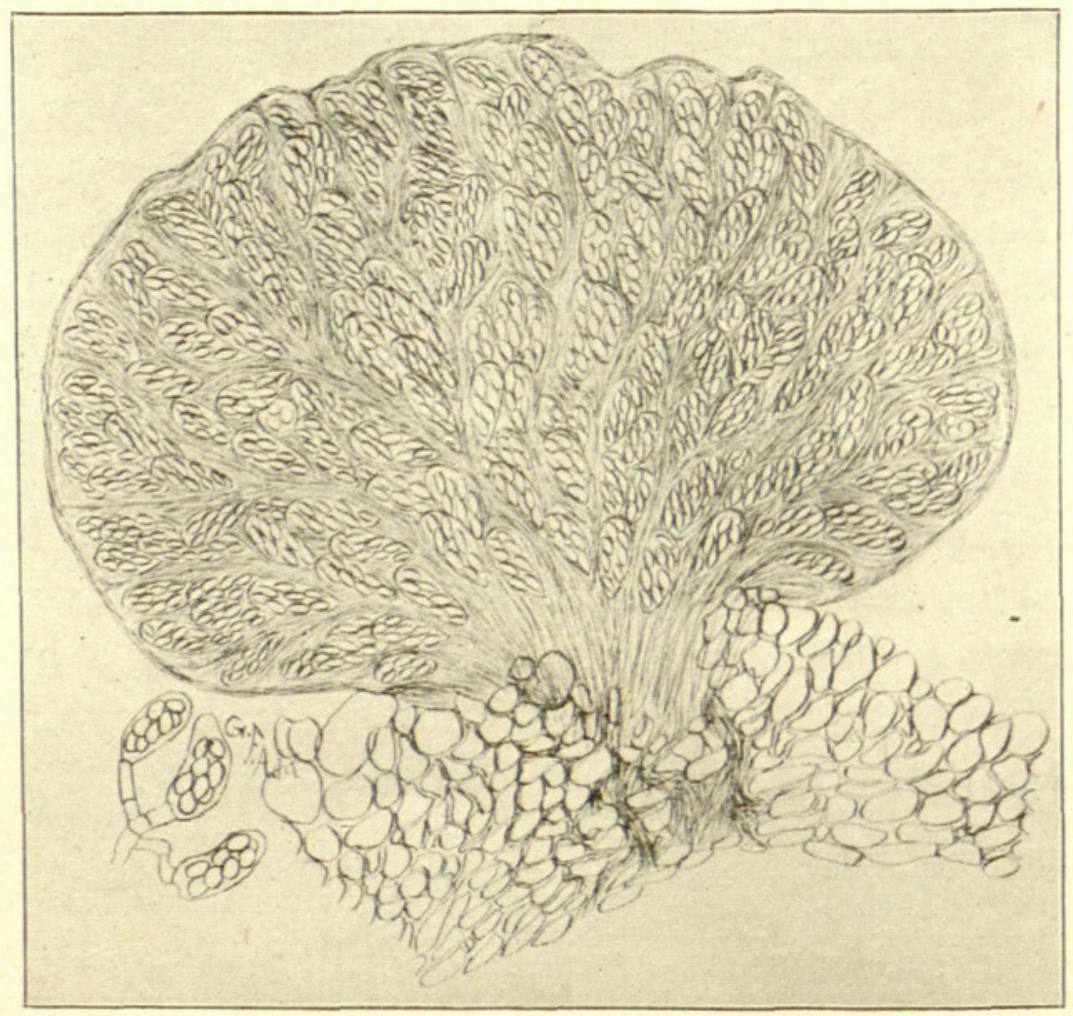

FIG. 2. Eoterfesia parasitica, showing section of fruit body and portion of perithecial wall of Sordaria.

not only a new generic type, but also the type of a new family. These may be characterized as follows :

EOTERFEZIACEAE Atkinson, n. fam.-Fruit bodies with a thin but distinct wall of closely interlaced hyphae. Interior with sterile avenues connected with the wall and separating the fertile areas where the asci are irregularly arranged.

EOTERFEZIA Atkinson, n. gen.-Fruit bodies subglobose, minute, fleshy, with a distinct but very thin, undifferentiated wall, smooth or slightly hairy. Interior of fruit body with sterile avenues radiating from the base and branching until they unite with the wall. Fertile areas lying between containing the asci 
intermingled with the supporting hyphae. Spores smooth, hyaline, one-celled. Interior not disintegrating into a powdery mass at maturity. At present one species as follows:

Eoterfezia parasitica Atkinson, n. sp.-Fruit bodies subglobose to kidney shaped, white, fleshy, I00-300 $\times$ I00-200 $\mu$, sessile, closely attached to the perithecia of the host, the mycelium issuing from the inside of the perithecium in a broad, stout strand, and then radiating. Wall of the fruit body distinct and well differentiated, but very thin $(3-5 \mu)$, membranaceous, and undifferentiated, with here and there rather long free branches of mycelium, but not distinctly hairy. Sterile avenues radiating from the point of attachment with the host, and branching as they approach the periphery, thin, but distinct, and separating the fertile areas into thin plates in which the asci are intermingled with the hyphae. Asci elliptical-oblong, I 5-20 $\times$ 8-10 $\mu$. Spores elliptical-oblong, smooth, 3-3.5 $\times$ I.5-2 $\mu$, biseriate.-Parasitic on perithecia of a Sordaria, Ithaca, N. Y.

It might be as well to consider the position which the Eoterfeziaceae occupy in relation to the other families of the Plectascineae. When I first discovered the plant, I was impressed with the resemblance of the asci and spores to those of Ascocorticium of the Protodiscineae, and those of some species of Endomyces of the Protoascineae. It is probably more nearly related to the latter. But the Gymnoascaceae, especially the genus Arachniotus, show very close relationship to Endomyces, both in the arachnoid envelop and in the undifferentiated condition of the fertile portion. Eoterfezia is perhaps an offshoot from such a plant as Arachniotus. The relationship of the families might be suggested by the following scheme:

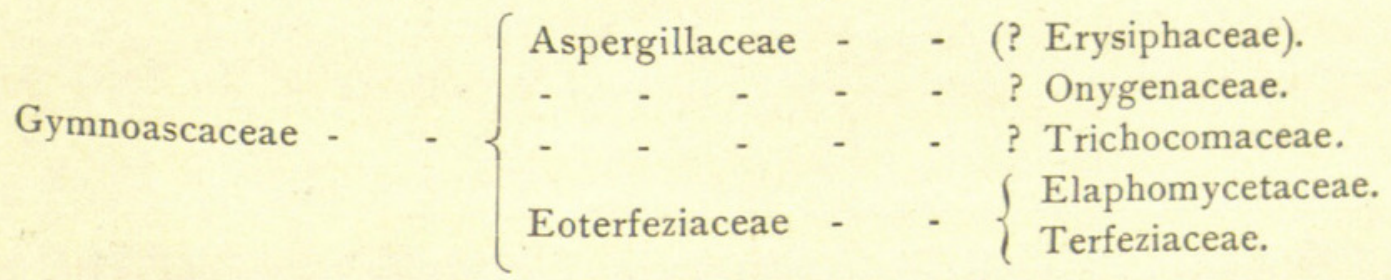

KEY TO THE GENERA OF PLECTASCINEAE.

Interior of fruit body undifferentiated,

Wall of fruit body arachnoid, simple

Gymnoascaceae

Wall of the fruit body firm, thick,

Fruit bodies not stalke

Aspergillaceae

Fruit bodies stalked

Onygenaceae 
Interior of fruit body differentiated,

Wall of fruit body very thin, membranaceous

Eoterfeziaceae

Wall of fruit body stout,

Spore mass powdery -

Spore mass not powdery

- Elaphomycetaceae

Terfeziaceae

Interior of fruit body with a highly specialized capillitium

Trichocomaceae

iII. Dictybole, A NEW GenUS OF PHALloids.

This plant was collected by W. H. Long, Jr., at Denton, Texas, Oct. I 5, I90I. It is peculiar and striking in that it possesses a dimorphic gleba, the upper part of which is traversed by sterile, radiating, imbricate plates suggesting the gleba of Itajahya, while the lower part of the gleba is latticed something after the fashion of Simblum. From the gross characters of the gleba it would seem to occupy an intermediate position between the two genera, the former being placed by Fischer in the Phallaceae, while the latter is a member of the Clathraceae. However, in Itajahya the sterile plates are pseudoparenchymatous, while in Dictybole they are floccose, and Dictybole therefore belongs in the Clathraceae.

The upper part of the volva in the specimens seen remains adherent to the pileus, so that in the elongation of the receptacle the volva ruptures in a circumscissle manner, leaving the edge of the pileus more or less irregularly lobed and pendent around the upper part of the receptacle, though sometimes the volva ruptures so high up that there is no free portion projecting. As the plant ages, the latticed portion of the gleba loosens from the stipe, except at the junction with the upper part of the pileus, and expands in such a manner as to form a pendent, loose, open, large meshed irregular network, which becomes easily torn asunder in several places. The plant when fresh has a peculiar, but pleasant and strong "amyl-acetate" odor. It represents the type of a new genus ${ }^{7}$, which may be characterized as follows :

DICTYBOLE Atkinson, n. gen.-Receptacle a hollow stalk with a chambered wall bearing at the apex a weakly devel-

${ }^{7}$ Dr. Ed. Fischer, to whom the plant was submitted, confirms my opinion that it represents a new genus. 
oped pileus covered by the gleba. Gleba dimorphic, the apical portion traversed by numerous sterile, short, radiating plates; the lower portion with convoluted folds in the form of irregular rings giving a latticed appearance to this portion of the gleba. At maturity the folds of the latticed portion of the gleba uncoil more or less and form long, irregu: lar, loose, netlike folds. Spores single celled, smooth.- One species, Denton, Texas.

Dictybole texensis Atkinson \& Long, n. sp.-Plants subterranean, emerging by the elongation of the receptacle, $7-10^{\mathrm{cm}}$ high. Receptacle nearly cylindrical, slightly tapering downward, cream white, firm; pileus not perforated at the apex, usually pendent from apex of receptacle, and upper part of volva often in contact. Gleba at first

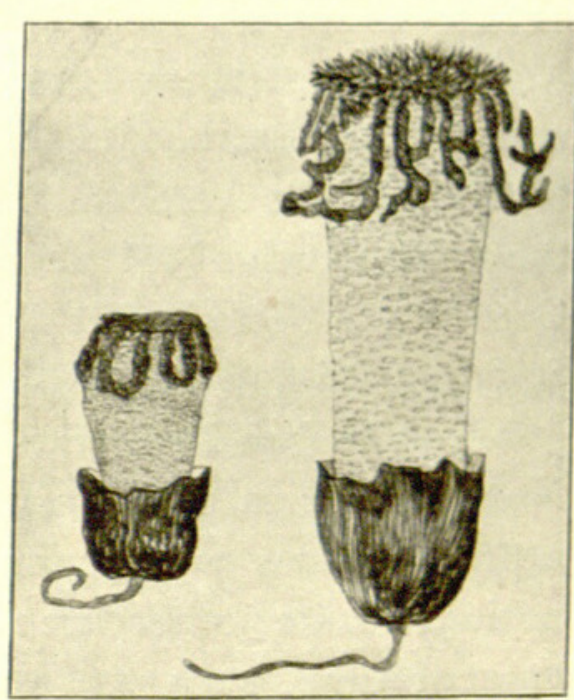

FIG. 3.-Dictybole texensis. drab, then black; sterile plates in upper part of gleba numerous, short, and narrow, arranged in a more or less radiating and imbricated manner; latticed portion with large oblong rings (8-16?), the surface rugose, and in age loosening out into a large open, irregular mesh. Spore bearing tissue between the sterile plates and lying between and over the lattice work. Spores pale olive brown, irregularly oval, 3-4 $\times 2-3 \mu$, smooth. Volva large, white, circumscissle, rooting at the base. The plant when fresh has a pleasant but strong "amyl-acetate" odor.-In sandy soil. Denton, Texas.

Botanical Department, Cornell University. 


\section{$2 \mathrm{BHL}$ Biodiversity Heritage Library}

1902. "Three New Genera of the Higher Fungi." Botanical gazette 34(1), 36-43. https://doi.org/10.1086/328258.

View This Item Online: https://www.biodiversitylibrary.org/item/91645

DOI: https://doi.org/10.1086/328258

Permalink: https://www.biodiversitylibrary.org/partpdf/223119

\section{Holding Institution}

Missouri Botanical Garden, Peter H. Raven Library

\section{Sponsored by}

Missouri Botanical Garden

\section{Copyright \& Reuse}

Copyright Status: Public domain. The BHL considers that this work is no longer under copyright protection.

This document was created from content at the Biodiversity Heritage Library, the world's largest open access digital library for biodiversity literature and archives. Visit BHL at https://www.biodiversitylibrary.org. 